\title{
Kesadaran Berbangsa Dan Elite Baru Dalam Historiografi Buku Teks SMA Kelas XI Kurikulum 2006
}

\section{Andre Bagus Irshanto}

Prodi Magister Pendidikan Sejarah, Pascasarjana, Universitas Pendidikan Indonesia

\section{Abstrak}

Buku teks sejarah adalah salah satu hasil dari karya historiografi yang peruntukannya untuk kepentingan pendidikan terutama untuk dijadikan bahan acuan untuk mengajar di kelas oleh guru, dan bagi siswa buku teks dijadikan sebagai salah satu sumber belajar sejarah. Dalam buku teks sejarah selain sebagai alat pendidikan juga dapat digunakan sebagai alat untuk menanamkan ideologi atau faham tertentu melalui peristiwa sejarah yang disesuaikan dengan rezim yang berkuasa saat itu pada massa orde baru buku teks sejarah sangat kental akan unsur ideologisme terutama pancasila dan militerisme dibandingkan dengan saintifisme keilmuan sejarah itu sendiri. Metode yang digunakan adalah metode analisis isi, yaitu memberikan penafsiran dan pemaknaan terhadap teks-teks yang berasal dari buku teks sejarah. Dalam tulisan ini penulis akan mengambil contoh historiografi buku teks pasca Orde Baru yaitu buku teks sejarah ketika diberlakukannya kurikulum 2006 (KTSP) pada kelas XI jurusan IPS dengan bab yang akan dikaji mengenai masa pergerakan nasional (1908-1942). Dalam buku tulisan ini akan mengkaji mengenai konsep elite baru dan kesadaran berbangsa pada massa pergerakan nasional.

\section{Kata Kunci: Historiografi, Buku Teks, Elite Baru}

\section{Pendahuluan}

Buku teks sejarah adalah salah satu karya historiografi yang diperuntukan dalam dunia pendidikan terutama pada dunia persekolahan tingkat SMA yang memiliki sasaran kepada guru dan siswa, selain memiliki fungsi sebagai alat pendidikan buku teks sejarah memiliki fungsi lain yang disesuaikan dengan kepentingan pemerintah yang berkuasa saat itu yang diatur di dalam kurikulum. Pada awal dekade 1950an hanya terdapat dua buku teks pelajaran sejarah terutama digunakan untuk tingkat SMA yang karya Anwar Sanusi dan Sanusi Pane dan masih digunakan sampai tahun 1960 an, apabila dilihat dari sumber rujukan atau bahan untuk menulis buku tersebut adalah bersumber dari karya tulis orang Belanda terutama buku Stapel yang sangat kental akan nuansa Neerlandosentrisme, walaupun dengan kelahiran kedua buku tersebut menjadi titik awal kesadaran bangsa Indonesia untuk menulis sejarah masa lalunya terutama yang digunakan untuk dunia pendidikan. Kedua buku tersebut sudah mengarah pada penulisan Indonesiasentrisme. Hal ini dapat kita lihat pada judul buku karya Sanusi Pane yang tidak lagi memberikan judul Sejarah Hindia Belanda tetapi Sejarah Indonesia. Dalam sistematika penulisan kedua buku tersebut baik Anwar Sanusi maupun Sanusi Pane sangat mirip dengan 
susunan bab yang ada di buku Stapel. Usaha perubahan arah penulisan sejarah Indonesia dari Neerlandosentrisme mengarah ke Indonesiasentrisme baru dilakukan secara serius pada tahun 1957 dengan digelarnya seminar nasional $1 \mathrm{di}$ Yogyakarta. Seminar nasional tersebut menghasilkan sebuah dekolonisasi terhadap historiografi Indonesia yang Indonesiasentrisme.

Hal ini berdampak kepada dunia pendidikan terutama jenjang menengah yaitu dengan pemberlakuan kurikulum oleh pemerintah yang berdampak juga terhadap penulisan buku teks sejarah yang dihasilkan yaitu yang bercorak gaya penulisan Indonesiasentrisme. Terdapat tiga buku teks yang bercorak Indonesiasentrisme yang ditulis oleh $\mathrm{Z} \mathrm{H}$ Idris, Soeroto, dan Soendhoro. Setelah perombakan historiografi buku teks sejarah dari Neerlandosentrisme menuju ke arah Indonesiasentrisme, penulisan buku teks sejarah memasuki babak baru.

Yaitu sebagai alat untuk membentuk warganegara yang baik termasuk di dalamya sejarah yang ditandai dengan pemberlakuan kurikulum 1961 dan disempurnakan oleh kurikulum 1964 yang dikenal dengan kurikulum SMA Gaya Baru atau kurikulum Pancawardhana. Tujuan pokok kurikulum ini adalah untuk mempersiapkan para siswa untuk melanjutkan ke jenjang yang lebih tinggi dan diharapkan menjadi warga negara patriot yang paripurna berguna bagi nusa dan bangsa dalam rangka pengabdian pada tanah air. Pada masa itu orientasi mata pelajaran sejarah termasuk di dalamnya gaya penulisan buku teks lebih berorientasi kepada pencapaian revolusi Indonesia yang harus mengandung:

1. Proklamasisentris

a) Semua perjuangan bangsa Indonesia dimulai sejak abad ke 17 sampai puncaknya adalah pada peristiwa kemeredekaan pada 17 Agustus 1945.

b) Zaman kejayaan sebelum abad ke 17 dimulai ketika Sriwijaya dan Majapahit menjadi imperium besar selalu memberikan semangat dan inspirasi dan semangat perjuangan pada masa kemerdekaan ini. Proklamasi 17 Agustus 1945 sampai pada zaman pembentukan masyarakat sosialis Indonesia, ini berarti bahwa sejarah setelah 17 Agustus 1945 bertujuan merealisasikan cita-cita proklamasi.

2. Bereksatologi pada masyarakat Indonesia yang sosialis

a) Sejak dahulu gerak sejarah bangsa Indonesia menuju kepada pembentukan masyarakat yang adil dan makmur atau masyarakat sosialis berdasarkan Pancasila.

b) Dalam memberikan sebuah tinjauan fakta-fakta sejarah haruslah selalu berpedoman kepada diperteguhnya 
dan terwujudnya cita-cita masyarakat sosialis Indonesia.

Ketika kurikulum Pancawardhana diberlakukan golongan komunis sangat mendukung dengan alas bahwa sistem pendidikan sebelumnya hanya berorientasi kepada pengetahuan saja, seharusnya siswa didik untuk mampu mempraktekkan ilmu yang telah di dapatkan ke dalam kehidupan sehari-hari. Alasan lain mengapa golongan dari komunis yang berafiliasi dengan PKI mendukung Pancawardhana adalah karena para anggota dari Lembaga Pendidikan Nasional (LPN) yang membuat kurikulum adalah berafiliasi dengan komunisme.

Karena orang-orang yang duduk di LPN berafilasi dengan Komunisme dan pada saat itu PKI sedang memiliki hubungan yang cukup mesra dengan pemerintah Soekarno maka segala usulan langsung cepat dikabulkan oleh pemerintah. Unsur-unsur ideologi sosialisme yang mengarah kepada komunisme sangat kentara pada bukubuku teks sejarah. Kejayaan kaum komunis segera berakhir ketika meletusnya G $30 \mathrm{~S}$ pada tahun 1965 dan semua ajarannya diberangus dan dilarang tetapi untuk kurikulum baru tahun 1968 baru muncul kurikulum yang baru.

Kurikulum 1968 yang diberlakukan pada masa awal Orde Baru ini memiliki misi sebuah misi politik, yaitu ingin memberangus ajaran komunisme sampai ke akar-akarnya terutama yang ada dalam dunia pendidikan Buku teks yang muncul pada masa kurikulum 1968 adalah memiliki tujuan:

1. Berpusat di Indonesia sejarah yang lebih bersifat Indonesiasentrisme dan meninggalkan Regiosentrisme dan Senosentrisme.

2. Pancasila bahwa Sejarah Nasional Indonesia adalah harus ikut membentuk siswa menjadi warga Negara yang panacasilais.

3. Undang-undang Dasar 1945 (Mukadimah UUD 1945) ... bahwa kemerdekaan adalah hak segala bangsa.

4. Menanamkan penghayatan kepada siswa mengenai riwayat perjuangan bangsa Indonesia.

5. Sejarah Nasional Indonesia menjadikan bangsa Indonesia sebagai actor utama sejarah bangsanya .

6. Bhineka Tunggal Ika perjuangan nasional juga diwujudkan dalam perjuangan-perjuangan regional.

Tidak jauh berbeda dengan massa sebelumnya yaitu pada massa Orde lama pada massa Orde baru juga menggunakan buku teks sebagai sarana untuk menyebarkan ideologi dengan titik tolak mengenai arti penting subjektif yaitu masa lampau dipelajari bukan demi pengetahuan tetapi demi lambang yang bisa diadakannya untuk masa kini (Abdullah \& Surjomihardjo, 1985: 27-28; Mulyana, 2009: 80) dan militerisme adalah 
bagaimana ideologi militer memberikan sebuah warna dalam historiografi buku teks. Pemasukan ideology dan militerisme dalam penulisan buku teks sejarah nasional untuk SLTA (Mulyana, 2013: 83) dengan tujuan untuk membentuk watak kebangsaan warganya dalam hal ini adalah siswa yang duduk dibangku SMA. Penanaman ideologi terhadap buku teks sejarah yang dilakukan pemerintah Orde baru dilakukan saat diberlakukan kurikulum 1984, khusus untuk mata pelajaran sejarah kurikulum ini lahir.

Dikarenakan pengajaran sejarah pada kurikulum sebelumnya yaitu kurikulum 1975 dianggap gagal karena dinilai kurang mampu menanamkan nilainilai berupa penghayatan terhadap perjuangan bangsa. Sejak diberlakukannya kurikulum 1984 terjadi dualisme pada mata pelajaran sejarah, yaitu Sejarah Indonesia dan Dunia dan PSPB (Pelajaran Sejarah Perjuangan Bangsa) yang diberlakukan pada tahun ajaran 1984/1985 pada semua tingkatan mulai TK sampai SMA.

Muatan ideologisme sangat kental sekali pada PSPB ini terlihat dari pemilihan materi yang terlebih dahulu dipilih hanya peristiwa tertentu yang mengandung nilai-nilai perjuangan atau kepahlawanan saja. Materi PSPB di SMA diberikan pada semua kelas mulai kelas satu sampai tiga dan semua jurusan dan hanya diberikan pada semester ganjil.
Untuk pembagian materinya mengacu kepada garis-garis besar program pendidikan sejarah perjuangan bangsa (GBPP PSPB) untuk sekolah menegah umum tingkat atas. Kepentingan pemerintah yang berkuasa sangat berperan penuh dalam penulisan buku teks sejarah pada masa itu dengan membawa misi yang bersifat ideologis dengan menyeleksi peristiwa sejarah yang dianggap penting dengan harapan setelah mengetahui peristiwa tersebut masyarakat (siswa) akan semakin memberikan pembenaran terhadap peristiwa-peristiwa sejarah yang memiliki nilai ideologi.

Kebenaran menegnai penafsiran peristiwa sejarah saat itu bersifat tunggal hanya yang berasal dari pemerintah. Pasca Orde Baru tumbang memasuki masa reformasi gaya historiografi buku teks yang bersifat ideologis yaitu mulai ditinggalkan lebih ditekankan pada sejarah yang bersifat lebih ilmiah yaitu suatu telaah kritis mengenai kehidupan masa lampau manusia dan lingkungannya berdasarkan metodemetode ilmiah (dalam hal ini metode sejarah) (Zed, 2002: 56).

Mulai massa reformasi dimulai pada pemberlakuan kurikulum 2004 sampai sekarang 2013 penulisan buku teks tidak lagi bersifat ideologis dan militeristik tetapi lebih menekankan kepada aspek ilmiah dari buku teks sejarah tersebut dengan tujuan memperkenalkan disiplin ilmu sejarah kepada siswa untuk 
mempersiapkan kepada jenjang perguruan tinggi, dan juga memberikan pengetahuan mengenai peristiwa sejarah sebagaimana apa adanya tanpa mengurangi atau melebihkan.

\section{Tinjauan Pustaka}

Penulis akan menguraikan sepuluh penelitian terdahulu dari jurnal yaitu:

1. Karya Andrew Jacob berjudul Nationalism In India dalam Sejarah: Journal of Departemen of History University Malaya, Vol. 25 No. 12016. Artikel membahas bagaimana nasionalisme terbentuk di India yang sangat berbeda dengan nasionalisme yang ada di Eropa. Nasionalisme yang lahir di India khususnya dan umumnya di Asia dan Afrika adalah karena sikap anti kolonialisme barat. Dalam proses lahirnya nasionalisme di India tidak mendiami waktu kosong yang melainkan waktu yang heterogen. Bahwa nasionalisme di India adalah sebuah proyek yang butuh mengembangkan dan dorongan rasa memiliki bersama diantara beragam orang di India. Rasa memiliki tersebut menjadi cikal bakal sebuah nasionalisme yang inklusif dan representatif.

2. Karya Low Cho Chin berjudul Aspirasi Liberalisme dan Sosialisme dalam mengintepretasikan Revolusi 1848 di Jerman dalam Sejarah: Jounal of Departemen History Vol. 23 No 2 Tahun
2014. Artikel membahas revolusi yang melanda Eropa termasuk Jerman di dalamnya 1848. Secara umum revolusi di Eropa termasuk Jerman di dalamnya adalah akibat tuntutan dari kalangan sipil kelas menengah mengenai pemberian hak yang sama dalam politik di parlemen yang terpengaruh oleh Ideologi nasionalisme. Di Jerman sebuah gerakan nasionalisme menuntut pembentukan sebuah parlemen berdasarngan kebangsaan Jerman yang waktu itu masih tercerai berai menjadi satu Negara bangsa. Pada tahun 1848 di Eropa sedang mengalami krisis sosioekonomi yang diakibatkan oleh bertambahnya jumlah penduduk, banyak industri, dan meningkatnya kemiskinan. Dalam revolusi 1848 ini golongan dari kelas bawah memiliki peran yang sangat penting dan lebih dominan dibandingkan dengan golongan kelas atas. Revolusi ini hanya bertahan satu setengah tahun saja, karena langsung ditumpas oleh pihak kekaisaran Jerman pada bulan Juli 1849. Terdapat empat aliran pemikiran dalam menyikapi revolusi di Jerman yaitu konservatif, liberal, radikal, dan sosialis. Bagi golongan konservatif, mereka merasa puas dengan keadaan Jerman sebelum revolusi 1848. Golongan ini tidak menganjurkan untuk adanya pemberontakan terhadap pemerintah mereka menyalahkan kaum intelektual 
saat itu yang memberi ajakan kepada rakyat untuk melawan pemerintah. Bagi golongan liberal lebih bersifat moderat yaitu mencoba mempertahankan kekuasaan lama dan memenuhi tuntutan revolusi. Golongan ketiga, golongan radikal berpendapat bahwa revolusi 1848 adalah sebuah cara yang dilakukan oleh rakyat untuk menghapuskan suatu lapisan yang telah menindas mereka yaitu pihak kekaisaran dan menggatinya dengan bentuk republik yang demokratik. Golongan ini menyelahkan kalangan borjuis yang memberikan sebuah janji palsu untuk gerakan pembaharuan. Sedangkan golongan terakhir yaitu golongan sosialis yang beranggapan bahwa revolusi itu adalah sebuah reaksi dari adanya masyarakat industry. Selain itu, tujuan kalangan sosialis selain ingin menggulingkan kekuasaan lama juga ingin memperbaharui sistem ekonomi yang sudah ada. Dalam revolusi ini yang menjadi aktor revolusi adalah kalangan kelas bawah seperti petani, buruh, pedagang, buruh perusahaan minyak, pedagang. Untuk kalangan menengah yang diwakili oleh kalangan intelektual hanya berperan sebagai pemberi sumbangan pemikiran saja. Tujuan dari revolusi ini sebenarnya adalah untuk melakukan pembaharuan terhadap sistem pemerintahan yang sudah ada. Revolusi ini digerakkan oleh kalangan moderat yang mendapat dukungan dari golongan kelas bawah dan mengalami kegagalan dan berhasil ditumpas oleh pihak dari kekaisaran Jerman.

3. Karya Nordin Husin berjudul A Critical review of the Early History Textbook in Malaysian Secondary School dalam Indonesian and the Malay World, Vol. 34 (106) Tahun 2008. Tulisan ini membahas penulisan buku teks di Malaysia pada masa penjajahan Inggris maupun masa sesudahnya yang masih dipegang oleh para pegawai karier dari Inggris. Artikel ini ingin membedah apakah ada sejarah Malaysia yang secara mandiri yang tidak ditulis oleh pegawai Inggris pada buku teks pelajaran di sekolah-sekolah pada menengah bawah, menengah pertama, dan menengah atas secara kritis.

4. Karya Rowland Atkinson, Simon Parker dan Roger Brown berjudul Elsite Formation, Power and space in contemporary dalam Journal Theory Culture \& Society, Vol. 34 (2) Tahun 2017. Artikel membahas kekuatan elite terutama di kota London yang menguasai kehidupan ekonomi dan politik di kota. Menurut Andreotti, dkk bahwa elite baru ini lahir dari kelompok kecil sosial di perkotaan atau diatas kelas menengah yang cenderung menentang elite nasional dan mereka berusaha mempromosikan ambisi mereka sendiri. Artikel ini penulis 
menempatkan kota London dalam hal fisik, politik, dan budaya. Disimpulkan bahwa konseptual elite sebagai kekayaan dan formasi kekuatan sosial yang ada dalam ruang spasial yaitu perkotaan.

5. Karya Marjo Nieminen berjudul From Elite Tradition to Midle Class Culture Images of Secondary education in the anniversary books of a finnish or School 1882-2007 dalam Journal Peadogica Historica: International Journal of the History of Education, Vol. 52 (3). Artikel ini membahas penggunaan sumber visual untuk membangun memori kolektif siswa di salah satu sekolah perempuan di Finlandia. Dengan fotafoto yang dijadikan sumber visual dimulai dari tahun 1882-2007 yang memungkinkan menjadi gambaran bagaimana perjalanan pendidikan di Finlandia terutama untuk sekolah anak perempuan.

6. Karya Jan Pakulski berjudul Introductiont: Jhon Higley's Work on Elite Foundations of Social Theoryand Politcs dalam Journal Historical Research, Vol. 37 No. 1 Tahun 2012. Tulisan ini mencoba menguraikan sebuah teori dari Jhon Higleys mengenai paradigma elite. Menurut Higleys bahwa elite adalah suatu actor sosial yang utama dan agen dari sebuah perubahan sosial dan politik. Fokus teori Higleys adalah menitikberatkan kepada hubungan antara karekteristik utama dari elite nasional. Terdapat prinsip utama seseorang dikatakan termasuk sebagai kalangan elite menurut Higleys, yaitu seseorang yang mempunyai posisi yang strategis dan memiliki pengaruh politik yang sangat massif dan substansial dan menggunakan kekuasaannya baik secara demokratis maupun non demokratis. Masih menurut Higleys bahwa seorang elite ketika berkuasa harus mampu berkultivasi dengan dukungan masa dan "membingkai bandingkan mereka agar sesuai dengan dan orientasi politik non elite". Dapat disimpulkan bahwa seorang elite harus mampu berbaur dengan segala golongan yang akan dipimpinnya. Terdapat pembagian elite nasional menurut transformasi menuju demokrasi adalah rezim demokrasi liberal dimana ekonomi pasar mengakar dan terkonsolidasi dimana elite nasional mencapai integrasi yang luas dan konsensus yang berkuasa tentang aturan keterlibatan politik. Sedangkan rezim tidak demokratis itu terbentuk karena ketidakstabilan politik.

7. Karya Monika Bolliger dalam Journal Bergann, Vol. 2 Nomor 2 Tahun 2017, berjudul Writing Syirian History While Prapagating Arab Nationalism: Textbook about modern Arab History under Hafiz and Bashar Al Ashad Tahun 2011. Artikel ini membahas buku teks 
sejarah yang ada di Suriah secara eksplisit mempropagandakan nasionalisme Arab dan diperkuat dengan semangat patriotism terutama ketika massa rezim Bashar Al Ashad. Ideologi nasionalisme yang sekuler yaitu nasionalisme Arab (Pan Arabisme) yang dibangun melalui buku teks sejarah di Suriah berasal dari Ba'tisht yaitu sebuah partai yang berkuasa di Suriah yaitu tidak membedakan agama manapun berasal. Ideologi nasionalisme yang terpengaruh dengan rezim $B a^{\prime}$ tisht terdapat pada buku teks sejarah pada jenjang kelas Sembilan dan kelas dua belas terutama sejak Bashar Al Assad. Buku teks sejarah di Suriah memainkan peranan yang cukup penting dalam membangun kesadaran sejarah pada diri siswa. Identitas nasional, disisi lain bahasa instutusi umum atau kesadaran sejarah umum. Di Suriah, menjadi otoritas tunggal dalam mengatur buku teks sejarah di Suriah.

8. Karya Mark Seiden, Yohiko, Nozoki berjudul Japannese textbook controversies Nationalism, and Historical memory Intra and national Conflict dalam Journal The Asian Pasific, Vol. 7 (2) Tahun 2009. Artikel ini membahas bagaimana terjadinya kontroversi pada buku sejarah di Jepang. Buku teks di Jepang pada tahun 1980an melakukan sensor kepada buku teks sejarah yang beredar yang dilakukan oleh Nakasone (seorang pejabat MOE yang menjabat sebagai perdana menteri yang berasal dari kalangan anti komunis). Pada massa Nakasone yaitu memasukan naskah nasionalis untuk siswa SMA Shinpen Nihonshin (edisi baru sejarah Jepang), yang telah ditunjuk oleh MOE dan diterbitkan pada tahun 1987. Kontroversi muncul dalam penulisan sejarah Jepang yang pertama kali muncul pada tahun 1990 terutama kejahatan Jepang pada massa perang yaitu mengenai wanita penghibur yang ditandai dengan ikut buka suaranya adalah korban dari wanita penghibur yang berasal dari Korea, lalu diikuti dari negara-negara lain di Asia. Pada tahun 1993 ketika itu Jepang dipimpin perdana menteri Kiichi mencoba menampung aspirasi dari korban wanita penghibur pada massa perang. Salah satu korban yang ikut bersuara yaitu lima belas wanita penghibur yang berasal dari Korea selatan. Masalah ini menjadi sebuah konflik internasional yang melibatkan Amerika serikat, Korea, Jepang, dan Cina. Penulis buku teks sejarah Jepang berjuang berasama dengan kaum sipil untuk melawan nasionalis Jepang dalam menciptakan kedamaian dan keadilan.

9. Karya Takahiro Kondo, Xiaoyan $\mathrm{Wu}$ berjudul A Comparative study of Patriotisme as goal of school education 
in China and Japan dalam Journal of Social Science education (JSSE), Vol. 10 No. 1 Tahun 2011. Artikel ini membahas bagaimana patriotism di Cina dalam perspektif Jepang lebih menekankan patriotisme beradasarkan asas-asas partai komunisme yang anti pada Jepang. Jepang khawatir akan pendidikan dan patriotisme di Tiongkok. Untuk mengatasi friksi berulang antara kedua Negara. Keduanya harus mengatasi ketidaktahuan mereka akan perbedaan yang diperlihatkan oleh Jepang dan China.

10. Karya Jhon Higley dan Jhon Pakulski berjudul Elite Theory versus Marxism: the Twenty centuries, dalam Journal of History Research, Vol. 37 (1) Tahun 2012. Artikel ini membahas bagaimana perbedaan teori elite dan teori marxisme yang memiliki akar yang berbeda. Teori marxisme dibangun dari akar pemikiran Hegel yang telah mengakar secara radikal yang menghasilkan sebuah sosialisme yang utopis. Sedangkan paradigm elite berakar dari pemikiran neo Katian dan lebih kepada pemikiran yang positivistik. Dasar-dasar dari teori Marxis adalah sebuah perubahan baik aspek sosial dan politik yang mengetengahkan kepada perjuangan kelas kaum proletar. Teori elite lebih menekankan kepada otonomi politik dengan menjalin hubungan vital antara kekuatan politik dengan kekuatan birokrasi untuk membentuk kelas solidaritas yang dapat merubah kehidupan masyarakat secara sosial maupun politik. Pada akhir abad ke 20 Marxisme terpecah menjadi beberapa aliran dan pada abad ke 20 juga teori elite tidak memiliki urgensi dalam percaturan dunia saat itu. Namun pada akhir abad ke 20, teori elite ini mulai dibangkitkan kembali oleh Negaranegara di Asia seperti Jepang lebih memfokuskan sektor eknomi.

\section{Metode Penelitian}

Metode yang digunakan dalam tulisan ini adalah metode analisis isi (content analysis). Metode anlisis ini adalah metode mengumpulkan dan menganalisis data dan menganalisis muatan dari sebuah teks. Teks yang dimaksud adalah teks yang terdapat dalam buku teks pelajaran SMA kelas XI Kurikulum 2006 mengenai pergerakan nasional. Dalam memberikan sebuah makna penulis menggunakan dua konsep yaitu elite baru dan kesadaran berbangsa.

\section{Hasil Dan Pembahasan}

\section{A. Elite Baru}

Dalam tulisan ini, mencoba mengangkat salah satu bab yang berjudul petumbuhan dan perkembangan nasionalisme di Indonesia dari buku teks sejarah kelas XI kurikulum 2006. Dalam pembahasan ini akan menguraikan dua 
konsep yaitu elite baru serta kesadaran berbangsa beserta contoh kutipannya yang terdapat pada buku teks. Istilah elite baru/anak-anak pergerakan, sebagai sekelompok generasi muda yang berusaha membongkar imanesi budaya masyarakat zamannya, mereka berjuang tidak hanya melalui bidang politik an sich, melainkan juga melalui transidensi kebudayaan (Hariyono, 2008: 269). Terdapat beberapa kutipan dari buku teks mengenai elite baru yang melakukan perjungannya melalui budaya.

Budi utomo memiliki tujuan meningkatkan pengajaran bagi orang Jawa, dan dalam perkembangannya, tujuan Budi Utomo diperluas dengan mencakup pendidikan barat dengan prioritas bahasa Belanda alasannya tanpa bahasa Belanda, seseorang tidak dapat menduduki suatu jabatan yang layak dalam jenjang kepegawaian Belanda (Alfian \& Soeyono, 2007: 201).

Terdapat cara lain yang dilakukan oleh elite baru untuk mencapai sebuah satu tujuan yaitu kemerdekaan melalui pendirian organisasi politik adalah sebagai berikut:

Pada tanggal 25 Desember 1912 lahirlah sebuah organisasi yang bercorak politik yang mendukung gagasan yang revolusioner yang bernama Indische Partij yang dicetuskan Douwes Deker yang lebih dikenal dengan nama Danudirdja Setiabudhi, organisasi ini lahir karena adanya keganjilan dalam masyarakat tubuh masyarakat saat itu, terutama untuk kaum Indo yang mengalami diskriminasi dari kalangan Belanda totok, selain itu juga melihat penderitaan yang dialami oleh rakyat Indonesia umumnya (Alfian \& Soeyono, 2007).

Analisis untuk kutipan yang pertama mengenai organisasi Budi Utomo yang anggotanya adalah warga yang telah tercerahkan dan terdidik salah satunya adalah Dr. Wahidin dan Dr. Soetomo yang memiliki latar belakang pendidikan Sekolah Dokter Jawa (STOVIA). Tampilan Budi utomo yang Jawaistis itu dapat dipahami sebagai sebuah kenyataan historis. Dalam kaitan itu, yang seharusnya di lihat dari Budi utomo bukan dari latar belakang etnis Jawa yang membentuknya, tetapi lebih kepada ide dasarnya untuk memajukan warga masyarakat negeri jajahan (Gonggong, 2013: 6).

Untuk analisis kutipan kedua mengenai lahirya Indische Partij sebagai organisasi politik pertama yang bersifat multirasional yang merumuskan ideologinya dengan nasionalisme Hindia, dan sikap politik mereka kepada pemerintah kolonial yang non kooperasi. Karena sikapnya itu anggota dari IP Douwes Dekker, Cipto Mangunkusumo, dan Raden Mas Suwardi Suryaningrat dijatuhkan hukuman pembuangan ke luar Hindia Belanda yaitu ke negeri Belanda. Selain mendirikan organisasi berbasis etno nasionalis dan politik para elite baru juga mendirikan sebuah organisasi yang berbasis keagamaan terutama agama Islam. Salah satu contohnya adalah organisasi 
Muhammadiyah yang masih eksis sampai sekarang.

Salah satu organisasi Islam yang cukup penting di Indonesia adalah Muhammadiyah yang didirikan pada 18 November 1912 oleh Kyai Haji Ahmad Dahlan dengan tujuan untuk menyebarkan ajaran Nabi Muhammad dan juga ingin memajukkan Islam dengan cara mendirikan lembagalembaga pendidikan tabligh-tabligh Islam, badan wakaf, serta menerbitkan buku-buku, brosur, majalah, dan surat kabar (Alfian \& Soeyono, 2007: 203).

Yang akan dianalisis dalam kutipan

ketiga ini adalah penggunaan surat kabar yang digunakan oleh Muhammadiyah untuk menyebarkan alirannya. Menurut Sartono Kartodirdjo (dalam Pradjoko, 1997: 422) bahwa dengan adanya surat kabar membentuk sebuah revolusi komunikasi, karena dapat menggeser bahkan merubah pola komunikasi tradsional (lisan) menjadi tertulis dalam bentuk surat kabar atau majalah. Dengan adanya media surat kabar terutama dengan tujuan untuk menyebarkan dakwah Islam yang akan memberikan pengaruh kepada pembacanya (Pradjoko, 1997: 422).

\section{B. Kesadaran Berbangsa}

Apabila dilihat secara historis dengan negara Malaysia terlebih dahulu membentuk sebuah negara dari pada membentuk sebuah bangsa sedangkan Indonesia sebaliknya. Dasar dari pembentukan kesadaran berbangsa Indonesia yang bersifat kulutural adalah dikarenakan faktor persamaan nasib, faktor bahasa, faktor agama yaitu Islam, faktor pengalaman sejarah yang merupakan ingredien utama bagi terwujudnya bangsa Indonesia (Maarif, 1997: 197).

$$
\text { Selain pernyataan diatas yang }
$$

menjadi penyebab lahirnya rasa kebangsaan adalah karena didorong oleh kesadaran bahwa antara kebudayaan masing-masing suku memiliki solidaritas di antara suku bangsa, dan dari sana tumbuh kesadaran berbangsa (Supardi, 2013: 89). Munculnya rasa berbangsa itu dimulai ketika berdirinya organisasi kemasyarakatan Budi Utomo (BU), dengan doktrin perjuangan adalah menumbuhkan semangat kebangsaan. Kesadaran tumbuh ketika mereka belajar di Belanda, dan banyak bergaul dengan pemuda-pemuda dari berbagai bangsa.

Pada tahun 1908 para mahasiswa terutama berasal dari kalangan bangsawan yang mendapatkan kesempatan untuk melanjutkan pendidikan di Belanda membuat sebuah perkumpulan yang diberi nama Indische Vereeniging (Perhimpunan Hindia) yang awalnya berbentuk sebagai perkumpulan sosial, perubahan orientasi perkumpulan ini adalah ketika kedatangan tiga serangkai dari Indische Partij dibuang ke Belanda. Pertumbuhan organisasi ini semakin pesat terutama setelah Perang Dunia I terutama setelah masuknya mahasiswa yang sedang menenmpuh studi lanjutan seperti Moh Hatta, Sutomo, Ali Sastroamindjojo, Budiarto, Iskaq, Iwa Kusumasumatri.

Dengan kehadiran dari para mahasiswa yang telah disebutkan diatas dapat awalnya sebagai 
mengubah wajah Perhimpunan Hidia yang awalnya perkumpulan sosial menjadi perkumpulan politik, dan pada Januari 1924 nama Indische Vereeneging (Perhimpunan Hindia) diubah menjadi bernama Indonesiche Vereeneging (Perhimpunan Indonesia) dan merubah arah perjuangan yang awalnya kooperatif menjadi non kooperatif yang antikolonial (Alfian \& Soeyono, 2007: 213).

Tidak kalah dengan para mahasiswa yang menuntut ilmu di Belanda para mahasiswa yang berada di Hindia Belanda mendirikan sebuah perkumpulan yang didirikan oleh Ir. Soekarno pada tahun 1925 yang diberi nama Alegmene Studie Club di Bandung yang corak dan gagasannya nasional dan radikal, dan pada tanggal 4 Juli 1927 atas inisiatif Soekarno Alegmene Studie Club berubah menjadi Perserikatan Nasional Indonesia (PNI) sebagai sebuah langkah untuk menampung gerakan nasionalis.

Sasaran pokok dari organisasi ini adalah tercapainya Indonesia merdeka. Jalan yang ditempuh oleh PNI adalah bersifat non kooperatif yaitu tidak mau bekerjasama dengan Belanda dan tidak mau duduk dalam dewan bentukan Belanda. Terdapat dua buah cara yang ditempuh oleh PNI untuk memperkuat dirinya dan melakukan propaganda berupa memperbesar pengaruhnya dalam masyarakat.

Pertama, adalah kedalam yakni mengadakan kursus, mendirikan sekolah, bank, dan sebagainya. Kedua, adalah dengan mengadakan rapat umum dan menerbitkan surat kabar (Persatoean Indonesia, Banteng Priangan). Kegiatan PNI tersebut cepat menarik masa dan membuat pemerintah kolonial Belanda khawatir maka pmerintah kolonial Belanda mengeluarkan ancaman terhadap PNI, meskipun telah mendapatkan teguran dan acaman PNI terus berjalan. Sampai tersebar isu bahwa PNI melakukan sebuah pemberontakan, akibatnya pemerintah Belanda melakukan penangkapan terhadap orang-orang yang dicurigai.

Maka pada tanggal 29 Desember 1929, Soekarno dan kawan-kawan ditangkap di Yogyakarta dan selanjutnya dibawa ke Bandung. Karena terjadinya peristiwa penangkapan aktivis PNI, maka diadakan aksi solidaritas yang diselenggarakan di Belanda yang diadakan oleh Perhimpunan Indonesia, Partai Buruh, dan Partai Komunis. Penangkapan aktivis PNI terutama Soekarno merupakan pukulan yang sangat keras bagi kaum nasionalis. Oleh sebab itu, pada kongres di Jakarta bulan April 1931 diputuskan untuk membubarkan PNI.

Sampai tahun 1926 belum ada satu wadah untuk mempersatukan organisasiorganisasi yang ada untuk mengadakan sebuah kongres. Kongres yang pertama diselenggarakan di Jakarta pada tanggal 30 April-2 Mei 1926. Hasil dari Kongres Pemuda I adalah menerima dan mengakui cita-cita persatuan walaupun belum samar- 
samar dan belum jelas dengan dibuktikan dengan membentuk sebuah wadah tunggal. Mereka masih meneruskan usahanya sampai dilaksanakan Kongres Pemuda II. Kongres pemuda II dilangsungkan pada 2628 Oktober 1928 yang dihadiri oleh 750 orang dari sembilan organisasi pemuda. Hasil dari kongres pemuda II adalah sebagai berikut:

Hasil kongres pemuda II adalah menghasilkan Sumpah Pemuda yang diikrarkan oleh para pemuda yang hadir dengan mengucapkan sumpah setia Satu Nusa, Satu Bangsa, dan Satu Bahasa Indonesia (Alfian \& Soeyono, 2007: 221).

\section{Penutup}

\section{Kesimpulan}

Buku teks sejarah adalah salah satu karya historiografi yang diperuntukkan untuk pendidikan sebagai salah satu sumber belajar bagi sejarah bagi siswa dan sebagai bahan mengajar bagi guru. Historiografi buku teks sejarah selalu mengikuti perkembangan pemerintahan yang berkuasa saat itu. Tulisan ini memaparkan mengenai salah satu bagian dalam buku teks yaitu mengenai sejarah pergerakan dengan menggunakan konsep elite baru dan kesadaran kebangsaan. Era kini yang berperan sebagai motor adalah kaum elite baru dan melahirkan kesadaran kebangsaan melalui organisasi-organisasi.

\section{Daftar Pustaka}

Alfian, M., \& Soeyono, N. N. 2007. Sejarah Untuk SMA dan MA Kelas XI Pragram
Ilmu Pengetahuan Sosial. Jakarta: Esis.

Abdullah, T., \& Surjomihardjo, A. 1985. Arah Gejala Dan Perspektif Studi Sejarah Indonesia. dalam Taufik Abdullah \& Abdurachman Surjomihardjo. Ilmu Sejarah dan Historiografi Arah dan Perspektif (hal. 27-28). Jakarta: Gramedia Pustaka Utama.

Gonggong, A. 2013. Humanisme, Marxisme, dan Nasionalisme : Konfliik Ideologi Organisasi Pergerakan Dalam Mencapai Kemerdekaan. Dalam N. Khozin (Ed.), Indonesia Rumah Bersama Jakarta: Musem Kebangkitan Nasional Direktorat Jenderal Kebudayaan Kementrian Pendidikan dan Kebudayaan.

Hariyono. 2008. Anak-anak Pergerakan dan Pencerahan Budaya Indonesia. dalam Djoko Marihandono (Ed.), Titik Balik Historiografi Indonesia: Refleksi Perjalanan Prof $\operatorname{Dr} R Z$ Leirisa (hal. 269). Jakarta: Wedatama Widya Sastra bekerjasama dengan Departemen Sejarah FIB UI.

Maarif, A. S. 1997. Cita-Cita Pergerakan Nasional , Dan Bangunan Politik Bangsa Dalam Perspektif Sejarah Indonesia Modern. Dalam P. S. Haryono (Ed.), Kongres Sejarah Nasional 1996 Sub Tema : Studi Komparatif Dan Dinamika Regional (hal . 197). Jakarta: CV Putra Sejati Raya.

Mulyana, A. 2009. Historiografi Di Indonesia Dari Magis - Religius Hingga Strukturis. Bandung: Refika Aditama.

Pradjoko, D. 1997. Kenyataan Yang Tersembunyi: Dakwah Islam Dalam Pers Jawa Di Keresidena Surakarta Dan Yogyakarta 1916-1931. dalam P. S. Haryono (Ed.), Kongres Nasional Sejarah 1996 Sub Tema: Studi Komparatif Dan Dinamika Regional 
(hal. 422). Jakarta: CV Putra Sejati Raya.

Supardi, N. 2013. Relevansi Kesadaran Berbangsa Dan Kesadaran Berbudaya Bangsa. dalam K. Nur (Ed.), Indonesia Rumah Bersama (hal. 89). Jakarta: Museum Kebangkitan Nasional Direktorta Jenderal Kebudayaan Kementrian Pendidikan dan Kebudayaan.

Zed, M. 2002. Beberapa Catatan Tentang Epsitimologi Sejarah. dalam S. P. Sumitro (Ed.), Dari Samudera Pasai Ke Yogyakarta Persembahan Kepada Teuku Ibrahim Alfian (hal. 56). Jakarta: Yayasan Masyarakat Sejarawan Indonesia dan Sinergi Press.

Atkinson, R, Simon,P, Brown, R. 2017. Elite Formation,Power and Space in Contemporary Journal Theory Culture \& Society, 34(5-6),

Bollinger, M. 2011. Writing Syirian History While Propagating Arab Nastionalism: Textbook about Modern Arab History Under Hafidz and bashar Al Ashad Journal Bergann Vol. 2 (2).

Chin, L. C. 2014. Aspirasi Liberalisme, Nasionalisme dan Sosialisme dalam Mengimpretasikan Revolusi 1848 Di Jerman. Sejarah : Journal Of Higley, J , Pakulsi, J (2012) Elite Theory versus Marxism : the Twenty centuries, Historical social reserch Vol 37 (1)

Higley, J, Pakulsi, J. 2012. Elite Theory versus Marxism: the Twenty centuries, Historical social research, Vol. 37 (1).

Husin, N. 2008. A Critical review of the Early History Textbook in Malaysia Secondary School Indonesian and the Malay World, 36 (106): 451-461.
Jacob, A. 2016. Nationalism in India Sejarah: Journal of Departement of History University Of Malaya, 25 (1).

Kondo, T, Wu, X. 2011. A Comparative Study Of Patriotism as goal of school Intra education in China and Japan. Journal of Social Science (JSSE). Vol 10 (1).

Neiminen, M. 2016. From Elite Traditions to Middle Class Image of Secondary education in the anniversary book of a finnish of school 1882-2007. Journal Peadagogica Historica : International Journal of History of education, Vol. 52 (2).

Pakulski, J. 2012. Introductiont: Jhon Higley's Work on Elite Foundations of Social Theory and Politics. Histori Social Reserch, Vol 37 no1.

Seiden, M, Nozoki, Y. 2009. Japanese Textbook

Controversies Nationalisme, and Historical memory Intra and national conflict. Journal The Asia Pasific, Vol. 7 (2). 